\title{
The ability of mares to respond to treatment for uterine abnormalities diagnosed by endometrial biopsy and some causes for failure to respond - A review of 1099
} cases

\author{
S.W. Ricketts and A. Barrelet
}

Rossdale \& Partners, Beaufort Cottage Laboratories, High Street, Newmarket, UK

\begin{abstract}
Summary
The records of 1099 mare endometrial biopsy samples were reviewed retrospectively. Samples were submitted for histopathological assessments before and after treatment for acute endometritis or endometrosis or both. Results confirm the remarkable competence of equine uterine mechanisms of defence, regeneration and repair, in that 76-89\% of mares who are treated conventionally for acute endometritis resolve these histopathological abnormalities at the first attempt.

The most numerous cause of failure to respond to conventional treatments was pneumovagina, caused by poor perineal and vulval conformation, associated with anatomical ageing or immaturity and not correctable by Caslick's vulvoplasty surgery. Four cases were correctable by Pouret's perineoplasty surgery and, in the case of two immature maiden mares, by allowing time for natural perineal maturity to occur. Intrauterine foreign bodies were a cause of persistent acute endometritis in 3 cases. A necrotic placental remnant, a 'lost' swab tip and an infected nidus were responsible. Parturient or coital damage to the equine cervix ended the careers of two broodmares. Translumenal uterine adhesions were a cause of persistent acute endometritis in one case, which was not resolvable.

In spite of all efforts, the cause of one case to fail to respond to treatment for acute endometritis remains obscure. The mare repeatedly produced and pooled excessive uterine fluid during early oestrus without bacteriological evidence of primary infection, in spite of treatment for myometrial inadequacy. An endometrial functional abnormality was postulated.

This survey also suggests that $75-87 \%$ of mares can improve their degree of endometrosis following treatment with endometrial curettage. Therefore, this technique (Ricketts, 1985b) remains a logical option for appropriate cases, where degree of endometrosis is judged to be excessive for age. In contrast to evidence for the development of endometrosis with age (Ricketts and Alonso, 1991a), age of mare did not affect ability to respond to treatment in this series and all ages were represented in both the recovered and failed to recover groups.

An accurate diagnosis of equine endometrial disease and its cause is a prerequisite to appropriate treatment and satisfactory recovery. Limiting causes are often extra-endometrial, involving the perineum, cervix, lumenal foreign bodies or adhesions, emphasising the need for thorough complete genital examinations and the need to manage each mare as an individual. Videohysteroscopic examinations are an important diagnostic tool in equine gynaecology, particularly for those mares with persistent endometritis following conventional treatments.
\end{abstract}

Keywords:

equine, endometrial, pathology, treatment, response

Die Fähigkeit von Stuten, auf Behandlungen uteriner Veränderungen zu reagieren, die in der Endometriumbiopsie diagnostiziert wurden, und einige Gründe für ein Therapieversagen: Eine retrospektive Untersuchung von 1099 Fällen

Die Befunde von 1099 Stutenuterusbiopsien wurden retrospektiv analysiert. Die Biopsien wurden vor und nach der Behandlung einer akuten Endometritis, Endometrose oder einer Kombination beider Veränderungen entnommen. Die Studienergebnisse bestätigen, dass der equine Uterus über beachtliche Mechanismen für die Abwehr, Regeneration und Abheilung verfügt. Die erstmalige konventionelle Behandlung der akuten Endometritis führte im histopathologischen Sinn bei 76-89\% der Stuten zur Abheilung.

Die häufigste Rezidivursache ist die auch mit der Scheidenplastik nach Caslick nicht korrigierbare Pneumovagina. Diese wird durch anatomische Fehlstellungen des Perineums und der Scheide, entweder bedingt durch juvenile Unreife oder durch fortgeschrittenes Alter, hervorgerufen. In vier Fällen wurde die Scheidenplastik nach Pouret erfolgreich eingesetzt. In zwei Fällen der juvenilen Unreife korrigierten sich die anatomischen Perinealverhältnisse mit dem zunehmenden Alter. Intrauterine Fremdkörper waren bei drei Stuten die Ursache einer persistierenden akuten Endometritis. Die Fremdkörper waren: ein Stück nekrotische Plazenta, ein „verloren gegangener" Uterustupfer und ein infizierter Konzeptus. Bei zwei Stuten bedeuteten Geburts- oder Deckverletzungen der Zervix das Ende der Zuchtkarriere. Bei einer Stute führten intraluminale Uterusadhäsionen zu einer irreversiblen persistierenden akuten Endometritis.

Eine Stute blieb trotz aller Therapieversuche aus unerklärlichen Gründen unfruchtbar. Sie zeigte wiederholt intraluminale Flüssigkeitsansammlungen im frühen Östrus, ohne dass ein bakteriologischer Befund erhoben werden konnte. Die Stute sprach nicht auf eine Behandlung gegen myometriale Insuffizienz an. Somit wurde als Verdachtsdiagnose eine abnormale endometriale Funktion gestellt.

Diese Studie zeigt auch, dass in 75-87\% der Fälle der Grad der Endometrose durch eine endometriale Curettage verbessert werden kann. Es hat sich gezeigt, dass die Methode (Ricketts, 1985b) bei den Stuten mit einem dem Alter nicht entsprechenden fortgeschritten Grad der Endometrose eingesetzt werden kann. Obwohl der Grad der Endometrose mit dem Alter zunimmt (Ricketts und Alonso, 1991a), sprachen alle Altersgruppen mit abnormal stark fortgeschrittener Endometrose auf die Therapie an. Vertreter aller Altersgruppen kamen in beiden, den Erfolgs- und Misserfolgskategorien, vor. Die Voraussetzung für die erfolgreiche Behandlung einer endometrialen Erkrankung ist die exakte Diagnose und Abklärung der Ursache. Die erfolgslimitierenden Ursachen sind oft außerhalb des Endometriums, z. B. als Scheiden- und Zervixveränderungen, Fremdkörper oder Adhäsionen zu finden. Diese Tatsache weist darauf hin, dass die gründliche vollständige gynäkologische Untersuchung sowie die Notwendigkeit jede Stute als Individuum zu betrachten, für den Therapieerfolg unerlässlich sind. Die Videohysteroskopie ist eine wichtige Zusatzunter-suchungsmethode, besonders bei Stuten mit einer persistierenden therapieresistenten Endometritis.

Schlüsselwörter: Pferd, Endometrium, Pathologie, Behandlung, Antwort 


\section{Introduction}

It has long been recognised that mares have remarkable uterine mechanisms of defence, regeneration and repair (Hughes and Loy, 1969; Peterson et al., 1969; Kenney et al., 1975; Asbury et al., 1980; Ricketts, 1985a; Watson, 1988; Allen and Pycock, 1989; Troedsson et al., 1995). It is clear that this involves complex interactions of genital structure and function at both gross and cellular levels. Improvements in the understanding of these factors and how abnormalities develop have led to improvements in their prevention, diagnosis and treatment at studfarms. These improvements have contributed to progressive improvements in Thoroughbred fertility over the last two decades. Analysis of Weatherbys' Annual Returns for Mares shows that conception and live foal rates have risen from $77.5 \%$ to $88.9 \%$ and $68.1 \%$ to $80.9 \%$ (Fig. 1), and barren mare rates have fallen from $22.5 \%$ to $11.5 \%$ (Fig. 2) in a most encouraging manner.

The clinician's role is to assess every mare who ends the breeding season not in foal (i.e. barren) as an individual. It is important to use all relevant clinical and laboratory aids to examine all levels of her genital tract in order to make diagnoses of genital abnormality, assess their significance, apply logical treatments and then re-examine to confirm successful resolution. The aim is to return the mare to her individual optimal breeding condition in preparation for the next season (Ricketts, 1989a,b; Ricketts
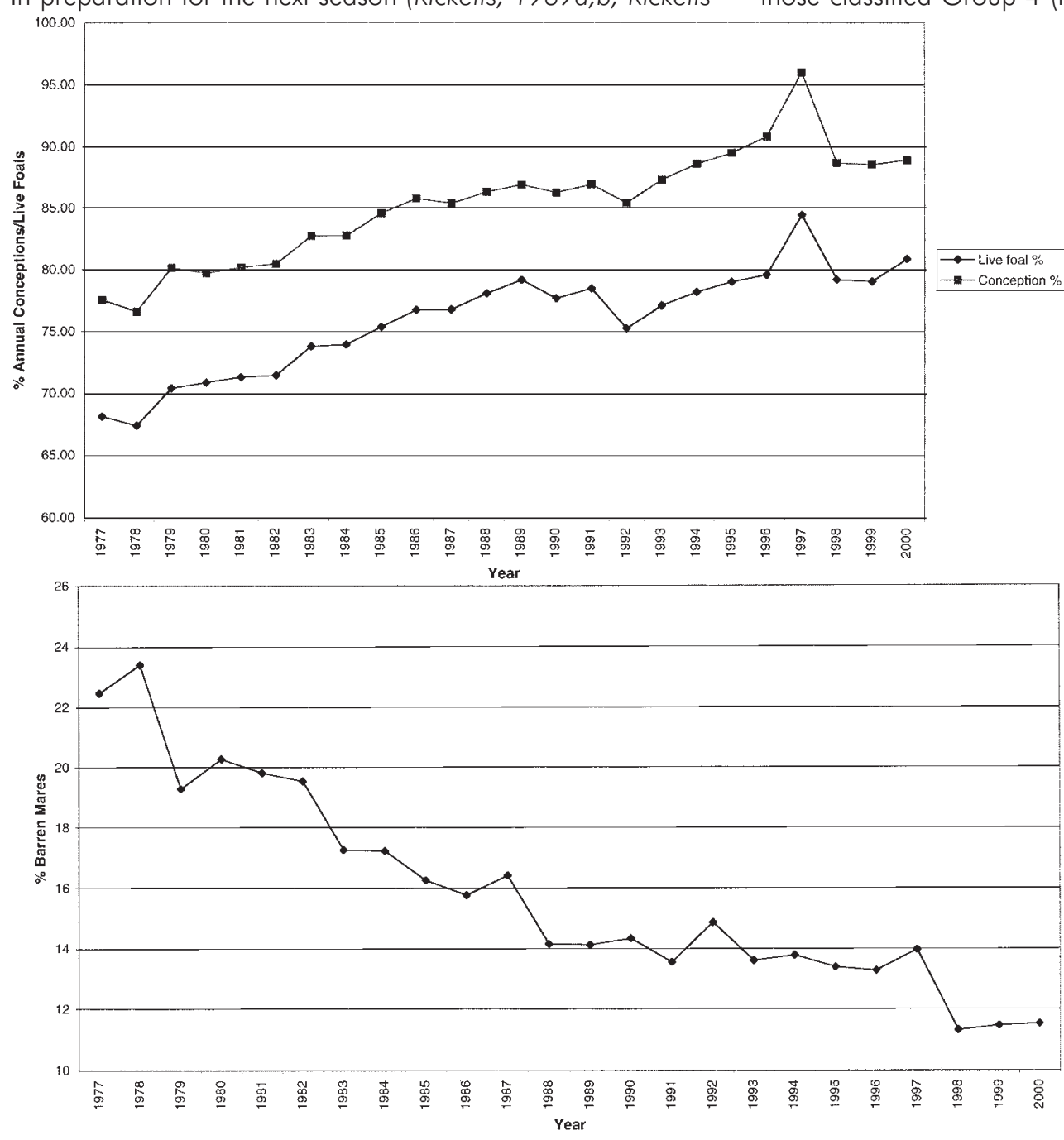

and Alonso, 1991a). This approach gives barren mares maximal opportunities to conceive early, which is to the advantage of their owners and busy studfarm managers.

An important part of the routine gynaecological assessment of barren mares is the histopathological assessment of endometrial biopsy specimens (Kenney, 1978; Ricketts, 1978). Ricketts and Alonso (1991b) analysed the results of 3804 endometrial biopsy examinations and showed that ageing is the most important factor in the development of chronic endometrial degenerative disease (endometrosis) in mares. Ricketts and Barrelet (1997) analysed the results of 4124 endometrial biopsy examinations, confirming widely held views on the pathogenesis and significance of histopathological abnormalities and showed that acute endometritis and endometrosis, alone or, more commonly, in combination, were the most commonly diagnosed abnormalities.

The ability of mares to respond to treatment for diagnosed endometrial pathology is an important assessment of the competence of their uterine mechanisms of defence, regeneration and repair. Ricketts and Alonso (1991a) analysed the results of 530 sets of paired endometrial biopsy examination results, before and after treatment. They showed that improvements in second biopsy prognostic classification and subsequent fertility was achieved in a significant proportion of mares, except those classified Group 4 (those with degrees of endometrosis
Fig 1: Weatherby's Annual Returns for UK and Irish Thoroughbred Mares - conception and life foal rates

Weatherbys' Jahresstatistik für UK und irische Vollblutstuten - Konzeptions- und Abfohlraten

Fig 2: Weatherby's Annual Returns for UK and Irish Thoroughbred Mares - number of barren mares

Weatherbys' Jahresstatistik für UK und irische Vollblutstuten - Anzahl güster Stuten 
considered to be markedly excessive for their age, signs of endometrial atrophy and those with pyometritis), where only $3 \%$ showed improvements. This survey aims to analyse the results of paired endometrial biopsy examinations in relation to the ability of mares to resolve acute endometritis and improve endometrosis, following treatment under studfarm conditions, and to identify some causes of failure to respond to treatment for acute endometritis.

\section{Materials and methods}

The records of 1099 mares (average age 11.7 years, range 323 years) from whom endometrial biopsy samples were submitted to the authors' laboratory for histopathological assessments were reviewed retrospectively (Table 1). The samples were paired biopsies collected before and after treatment (Ricketts and Alonso, 1991a) for acute endometritis (polymorphonuclear cell infiltrations) or endometrosis (chronic glandular degenerative changes and periglandular fibrosis) of a degree considered excessive for age (Ricketts and Alonso, 1991 b) or both. Mares with acute endometritis were treated with intrauterine antibiotic irrigations (Ricketts and Mackintosh, 1987; Ricketts, 1997) with or without large volume intrauterine saline flush and intravenous oxytocin treatment (Pycock, 1994; Ricketts, 1999), and Caslick's vulvoplasty surgery (Ricketts and Curnow, 1988), as appropriate to the case. Mares with endometrosis were treated with endometrial curettage (Ricketts, 1995b). Satisfactory response to treatment for acute endometritis was defined as resolution, i.e. no signs of polymorphonuclear cell infiltration. Satisfactory response to treatment for endometrosis was defined as improvement in degree of chronic endometrial degenerative change (glandular degenerative changes and periglandular fibrosis) to that which was considered to be within acceptable limits for the mare's age (Ricketts and Alonso, 1991 b).

In order to investigate specific cases of failure of response to treatment for acute endometritis, a subset of 122 mares (average age 9.6 years, range $3-20$ years) were selected (Table 2 ). These mares were examined and treated for acute endometritis and some also for excessive endometrosis, by the first author and sufficiently detailed clinical records were available for analysis of those who failed to respond (Table 3).

\section{Results}

Table 1 and 2 show that $76 \%$ of the 946 mares and $89 \%$ of the 122 subset mares treated for acute endometritis resolved after treatment, leaving $24 \%$ and $11 \%$ who did not, requiring further assessments and treatments. $75 \%$ of the 241 mares and $87 \%$ of the 15 subset mares treated for endometrosis improved after treatment, leaving $25 \%$ and $13 \%$ who did not improve.

Tables 1 and 2 show that mares treated for endometrosis were, on average, 2 years older than those treated for acute endometritis, as would be expected (Ricketts and Barrelet, 1997), but there were no obvious differences in the average ages of mares who did or did not respond to treatments. The range of ages in the 241 mares treated for endometrosis showed that both young and old mares were represented in both outcomes but in the subset of 15 mares treated by the first author, the average age of the 13 mares who responded to treatment was 13.1 years whereas the 2 mares who did not respond were aged 15 and 17 years.

The causes for failure to respond for the 13 mares who did not respond to treatments for acute endometritis are shown in Table 3. Four mares (aged 12-17 years) required Pouret's perineoplasty surgery (Pouret, 1982) to correct sufficiently poor perineal/ vulval conformation, not correctable by Caslick's vulvoplasty

Tab. 1: Analysis of the results of paired endometrial biopsy samples from 1099 mares in terms of their ability to respond to treatment for acute endometritis or endometrosis

Analyse der Ergebnisse der gepaarten Endometriumbiopsien von 1099 Stuten in Bezug auf ihre Fähigkeit auf eine Behandlung gegen eine Endometritis und Endometrose zu reagieren

\begin{tabular}{|c|c|c|c|}
\hline & & $\begin{array}{c}\text { Acute } \\
\text { Endometritis }\end{array}$ & Endometrosis \\
\hline \multirow[t]{4}{*}{ All mares* } & $\mathrm{N}$ & 946 & 241 \\
\hline & $\begin{array}{l}\text { Ave. age } \\
\text { (years) }\end{array}$ & 11.5 & 13.7 \\
\hline & $\begin{array}{l}\text { Min. age } \\
\text { (years) }\end{array}$ & 3 & 5 \\
\hline & $\begin{array}{l}\text { Max. age } \\
\text { (years) }\end{array}$ & 23 & 23 \\
\hline \multirow[t]{4}{*}{$\begin{array}{l}\text { Mares who responded } \\
* * \text { to treatment }\end{array}$} & N. (\%) & 721 (76\%) & 180 (75\%) \\
\hline & $\begin{array}{l}\text { Ave. age } \\
\text { (years) }\end{array}$ & 11.3 & 13.6 \\
\hline & $\begin{array}{l}\text { Min. age } \\
\text { (years) }\end{array}$ & 3 & 5 \\
\hline & $\begin{array}{l}\text { Max. age } \\
\text { (years) }\end{array}$ & 23 & 23 \\
\hline \multirow{4}{*}{$\begin{array}{l}\text { Mares who did not } \\
\text { respond*** to } \\
\text { treatment }\end{array}$} & N. (\%) & $225(24 \%)$ & $61(255)$ \\
\hline & $\begin{array}{c}\text { Ave. age } \\
\text { (years) }\end{array}$ & 12.2 & 14.2 \\
\hline & $\begin{array}{c}\text { Min. age } \\
\text { (years) }\end{array}$ & 4 & 5 \\
\hline & $\begin{array}{l}\text { Max. age } \\
\text { (years) }\end{array}$ & 23 & 23 \\
\hline
\end{tabular}

*All mares treated for either acute endometritis or endometrosis or both, and re-examined approximately 4 weeks later (Ricketts and Alonso 1991a)

**Satisfactory response to treatment for acute endometritis is defined as resolution, i.e. no longer signs of polymorphonuclear cell infiltration.

***Satisfactory response to treatment for endometrosis is defined as improvement in degree of chronic endometrial degenerative change (glandular degenerative changes and periglandular fibrosis) to that which was considered to be within acceptable limits for the mare's age (Ricketts and Alonso, 1991b). 
surgery, and all four subsequently resolved their persistent acute endometritis and produced live foals when mated during the subsequent breeding season. Two maiden (4 year-old) mares suffered persistent pneumovagina from very poor perineal and vulval tone, resulting in inadequate closure, in spite of Caslick's vulvoplasty surgery. Both mares resolved both their perineal conformation and their persistent acute endometritis, when their perineal fat pads had developed and one mare produced a live foal following her 5 year-old breeding season and the other following her 6 year-old breeding season, suggesting that this was a problem of anatomical immaturity. Two mares (aged 7 and 10 years) had cervical injuries sustained at previous parturition. One case was retired from stud duties and in the other case, unsuccessful attempts at surgical repair were made. In two mares (aged 6 and 8 years), intrauterine foreign bodies were identified during videohysteroscopic examinations (Bracher and Allen, 1992; Bracher et al., 1992) and were

Tab. 2: Analysis of the results of paired endometrial biopsy samples from 1099 mares treated for acute endometritis or endometrosis by the first author in terms of their ability to respond to treatment

Analyse der Ergebnisse der gepaarten Endometriumbiopsien von 122 Stuten, die vom Erstautor gegen akute Endometritis und Endometrose behandelt wurden, in Bezug auf ihre Fähigkeit auf die Behandlung zu reagieren

\begin{tabular}{|c|c|c|c|}
\hline & & $\begin{array}{c}\text { Acute } \\
\text { Endometritis }\end{array}$ & Endometrosis \\
\hline \multirow[t]{4}{*}{ All mares* } & N. & 122 & 15 \\
\hline & $\begin{array}{c}\text { Ave. age } \\
\text { (years) }\end{array}$ & 9.6 & 13.5 \\
\hline & $\begin{array}{l}\text { Min. age } \\
\text { (years) }\end{array}$ & 3 & 9 \\
\hline & $\begin{array}{l}\text { Max. age } \\
\text { (years) }\end{array}$ & 20 & 20 \\
\hline \multirow[t]{4}{*}{$\begin{array}{l}\text { Mares who responded } \\
* * \text { to treatment }\end{array}$} & N. (\%) & 109 (89\%) & 13 (87\%) \\
\hline & $\begin{array}{c}\text { Ave. age } \\
\text { (years) }\end{array}$ & 9.5 & 13.1 \\
\hline & $\begin{array}{c}\text { Min. age } \\
\text { (years) }\end{array}$ & 3 & 9 \\
\hline & $\begin{array}{l}\text { Max. age } \\
\text { (years) }\end{array}$ & 20 & 20 \\
\hline \multirow{4}{*}{$\begin{array}{l}\text { Mares who did not } \\
\text { respond*** to } \\
\text { treatment }\end{array}$} & N. (\%) & 13 (1 1\%) & $2(13 \%)$ \\
\hline & $\begin{array}{c}\text { Ave. age } \\
\text { (years) }\end{array}$ & 10.5 & 16 \\
\hline & $\begin{array}{c}\text { Min. age } \\
\text { (years) }\end{array}$ & 4 & 15 \\
\hline & $\begin{array}{l}\text { Max. age } \\
\text { (years) }\end{array}$ & 17 & 17 \\
\hline
\end{tabular}

legend see table 1 . removed using the biopsy attachment. One foreign body was found to contain inorganic filamentous material, suggesting that it was the remnant of a bacteriological swab tip and the other was a small structureless eosinophilic mass (Fig. 3) with a central core of Gram negative cocci, identified by bacterial culture as Escherischia coli. Both mares then resolved their

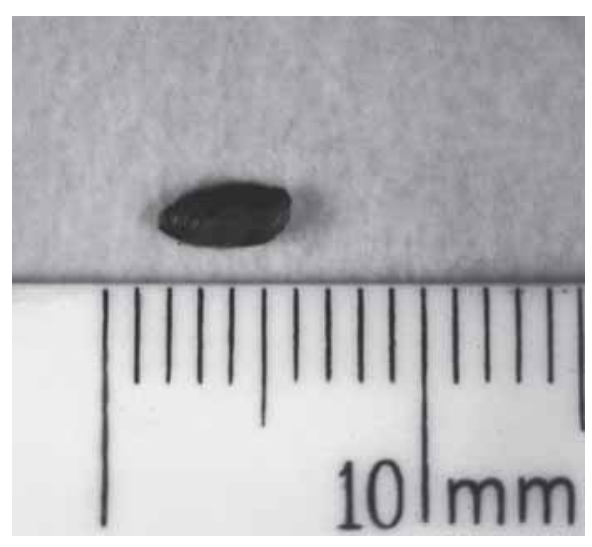

Fig. 3: Intra-uterine foreign body containing eosinophilic masses with a central core of Gram negative cocci.

Intrauteriner Fremdkörper bestehend aus amorphem eosinophilem Material mit Nachweis eines zentralen Herdes gram-negativer Kokken

acute endometritis following repeated intrauterine antibiotic and saline irrigations and produced live foals when mated during the subsequent breeding season. In one mare (aged 13 years), a necrotic placental remnant was identified during video-hysteroscopic examinations and removed using the biopsy attachment. This mare resolved her acute endometritis following repeated intrauterine antibiotic and saline irrigations and produced a live foal when mated during the subsequent breeding season. In one mare (aged 15 years), multiple trans-lumenal uterine fibrous adhesions were identified during video-hysteroscopic examinations. Attempts to remove them by laser ablation and endometrial curettage was unsuccessfu in that they reformed and persistent endometritis continued The mare remained barren thereafter but the cause of the adhesion formation was never established. In one mare (12 years), further examinations, including videohysteroscopic examinations, failed to identify a cause for her persistent acute endometritis. She repeatedly appeared to produce and poo excessive uterine fluid during early oestrus, succumbed to recurrent Streptococcus zooepidemicus and Escherischia col nfections, failed to respond to repeated treatments with antipiotic and saline irrigations and with intravenous oxytocir herapy and repeatedly failed to conceive in spite of the use o minimal contamination breeding techniques for natural mating (Kenney et al., 1975).

\section{Discussion}

This survey confirms the remarkable competence of equine uterine mechanisms of defence, regeneration and repair, in hat $76-89 \%$ of mares who are treated conventionally for acute 
endometritis, as diagnosed by the demonstration of polymorphonuclear leucocyte infiltration in biopsy samples, resolve these histopathological abnormalities at the first attempt. In this survey, age of mare did not affect ability to respond to treatment and all ages were represented in both the recovered and failed to recover groups.

The most numerous causes of failure to respond to conventional treatments were pneumovagina, caused by poor perineal and vulval conformation, associated with anatomical ageing or immaturity and not correctable by Caslick's vulvoplasty surgery. These cases are usually correctable by Pouret's perineoplasty surgery or, in the case of immature maiden mares, by allowing time for natural perineal maturity to occur. No cases of persistent urovagina were recorded in this series. Some of these cases will respond following Pouret's perineoplasty surgery but others may require urethral extension surgery (Easley, 1993).

Intrauterine foreign bodies are a significant, albeit uncommonly diagnosed cause of persistent acute endometritis. Necrotic placental remnants, 'lost' swab tips and infected nidi may be responsible. These may be identified during videohysteroscopic examinations and removed using the biopsy attachment. Therefore, if not part of the first post-breeding season barren mare examination, videohysteroscopic examinations should be selectively used for cases of persistent acute endometritis who have not responded to conventional treatment, so that intrauterine foreign bodies are detected and removed.

Parturient or coital damage to the equine cervix is a very serious injury in terms of subsequent fertility. Although high subsequent pregnancy rates following surgical repair of cervical lacerations have been reported (Brown et al., 1984), so have high incidences of subsequent abortion (Aanes, 1993) and the mare's age and genital health should be carefully and fully considered, with the owner's aspirations, before attempts at surgical repair are recommended.

Translumenal uterine adhesions are a cause of persistent acute endometritis. Whilst single or focal adhesions may not prevent some mares from producing a live foal (Van Camp, 1993), multiple and extensive adhesions are difficult to resolve because of their tendency to reform and are therefore a poor prognostic sign. The cause of the adhesion formation was not established in this case, but it is clearly important not to use irritant medication in the equine uterus (Ricketts, 1997).

In spite of all efforts, the causes of some cases to fail to respond to treatment for acute endometritis remains obscure. The case recorded in this series is not atypical in appearing to produce and pool excessive uterine fluid during early oestrus. This happens in spite of intensive and repeated treatments with intrauterine irrigations to flush out infection and inflammatory fluids, coupled with intravenous oxytocin therapy to promote myometrial activity (Pycock, 1994) and the absence of demonstrable cervical abnormality. Such cases appear to respond with a form of endometrial hypersensitivity. With current knowledge one can only postulate an endometrial functional abnormality, for which detailed pathogenesis remains unproven and means of correction and/or compensation remain undeveloped.

This survey also suggests that $75-87 \%$ of mares can improve their degree of endometrosis following treatment with endometrial curettage. Therefore, this technique (Ricketts, 1985b) remains a reasonable option for appropriate cases, where degree of endometrosis is judged to be excessive for age. In contrast to evidence for the development of endometrosis with age (Ricketts and Alonso, 1991a), in this survey, age of mare did not affect ability to respond to treatment and all ages were represented in both the recovered and failed to recover groups.

\begin{tabular}{|c|c|l|l|l|l|}
\hline Mare & Age (years) & Diagnosis * $^{*}$ & Diagnosis 2* & Problem/Solution & Result** \\
\hline 1 & 8 & $\mathrm{AE}+\mathrm{CIE}$ & $\mathrm{AE}+\mathrm{CIE}$ & Remove iu foreign body & Foal \\
\hline 2 & 7 & $\mathrm{AE}+\mathrm{CIE}$ & $\mathrm{AE}+\mathrm{CIE}$ & Cervical injury & Barren \\
\hline 3 & 4 & $\mathrm{AE}+\mathrm{CIE}$ & $\mathrm{AE}+\mathrm{CIE}$ & Poor perineal tone & Barren \\
\hline 4 & 12 & $\mathrm{AE}+\mathrm{CIE}$ & $\mathrm{AE}+\mathrm{CIE}$ & Not determined & Barren \\
\hline 5 & 15 & $\mathrm{AE}+\mathrm{CIE}+\mathrm{CDE}$ & $\mathrm{AE}+\mathrm{CIE}+\mathrm{CDE}$ & Uterine adhesions & Barren \\
\hline 6 & 17 & $\mathrm{AE}+\mathrm{CIE}+\mathrm{CDE}$ & $\mathrm{AE}+\mathrm{CIE}+\mathrm{CDE}$ & Pouret perineoplasty & Foal \\
\hline 7 & 12 & $\mathrm{AE}+\mathrm{CIE}+\mathrm{CDE}$ & $\mathrm{AE}+\mathrm{CIE}+\mathrm{CDE}$ & Pouret perineoplasty & Foal \\
\hline 8 & 6 & $\mathrm{AE}+\mathrm{CIE}$ & $\mathrm{AE}+\mathrm{CIE}$ & Remove iu foreign body & Foal \\
\hline 9 & 13 & $\mathrm{AE}+\mathrm{CIE}$ & $\mathrm{AE}+\mathrm{CIE}$ & Remove placental remnant & Foal \\
\hline 10 & 4 & $\mathrm{AE}+\mathrm{CIE}$ & $\mathrm{AE}+\mathrm{CIE}$ & Poor perineal tone & Foal \\
\hline 11 & 13 & $\mathrm{AE}+\mathrm{CIE}+\mathrm{CDE}$ & $\mathrm{AE}+\mathrm{CIE}+\mathrm{CDE}$ & Pouret perineoplasty & Foal \\
\hline 12 & 10 & $\mathrm{AE}+\mathrm{CIE}$ & $\mathrm{AE}+\mathrm{CIE}$ & Cervical injury & Retired \\
\hline 13 & 16 & $\mathrm{AE}+\mathrm{CIE}+\mathrm{CDE}$ & $\mathrm{AE}+\mathrm{CIE}+\mathrm{CDE}$ & Pouret perineoplasty & Foal \\
\hline
\end{tabular}

Tab. 3: Analysis of the 13 out of 122 mares who did not respond to treatment for acute endometritis

Analyse der 13 von den 122 Stuten, die nicht auf die Behandlung gegen die akute Endometritis reagiert haben 


\section{Conclusions}

As in all aspects of veterinary medicine, an accurate diagnosis of equine endometrial disease and its cause is a prerequisite to appropriate treatment and satisfactory recovery. The limiting causes are often extra-endometrial, involving the perineum, cervix, lumenal foreign bodies or adhesions, emphasising the need for thorough complete genital examinations and the need to manage each mare as an individual. Videohysteroscopic examinations are an important diagnostic tool in equine gynaecology, particularly for those mares with persistent endometritis following conventional treatments.

\section{Literature}

Aanes, W.A. (1993): Cervical lacerations. In Equine Reproduction, Ed. A.O. McKinnon and J.L. Voss, Williams and Wilkins, 444-449.

Allen, W.E. and Pycock, J.F. (1989): Current views on the pathogenesis of bacterial endometritis in mares with lowered resistance to endometritis. Vet. Record, 125, 298-301.

Asbury, A.C., Halliwell, R.E.W., Foster, G.W. and Longino, S.J. (1980): Immunoglobulins in uterine secretions of mares with differing resistance to endometritis. Theriogenology, 14, 299-304.

Bracher, V. and Allen, W.R. (1992): Videoendoscopic evaluation of the mare's uterus: I. Findings in normal fertile mares. Equine Vet. J., 24, 274-278.

Bracher, V., Mathias, S. and Allen, W.R. (1992): Videoendoscopic evaluation of the mare's uterus: II. Findings in subfertile mares. Equine Vet. J., 24, 279-284.

Hughes, J.P. and Loy, R.G. (1969): Investigations on the effect of intrauterine inoculations of Streptococcus zooepidemicus in the mare. Proc. 15 th Ann. Conv. Am. Ass. Equine Practnrs, 289-292.

Brown, J.S., Varner, D.D., Hinrichs, K. and Kenny, R.M. (1984): Surgical repair of the lacerated cervix of the mare. Theriogenology, 22, 351359.

Easley, J. (1993): Correction of vesicovaginal reflux. In Equine Reproduction, Ed. A.O. McKinnon and J.L. Voss, Williams and Wilkins, 428-436.

Kenney, R.M. (1978): Cyclic and pathologic changes in the mare endometrium as detected by biopsy with a note on early foetal death. J. Am. Vet. Med. Ass., 172, 241-262.

Kenney, R.M., Bergman, R.V., Cooper, W.L. and Morse, G.W. (1975): Minimal contamination techniques for breeding mares: techniques and preliminary findings. Proc. 21 st Ann. Conv. Am. Ass. Equine Practnrs., 327-336.

Peterson, F.B., McFeely, R.A. and David, J.S.E. (1969): Studies on the pathogenesis of endometritis in the mare. Proc. $15^{\text {th }}$ Ann. Conv. Am. Ass. Equine Practnrs, 279-287.

Pouret, E.J.M. (1982): Surgical techniques for correction of pneumoand urovagina. Equine Vet. J. 14, 249-250.

Pycock, J.F. (1994): A new approach to treatment of endometritis. Equine Vet. Education, 6, 36-38.
Ricketts, S.W. (1978): Histological and histopathological studies on the endometrium of the mare. Fellowship Thesis, R.C.V.S., London.

Ricketts, S.W. (1985a): Dealing with the "problem mare". Equine Vet. J., 17, 3.

Ricketts, S.W. (1985b): Endometrial curettage in the mare, Equine Vet. J., 17,324-328.

Ricketts, S.W. (1989a): The barren mare: Diagnosis, prognosis, prophylaxis and treatment for genital abnormality. Part 1. In Practice, $11,119-125$.

Ricketts, S.W. (1989b): The barren mare: Diagnosis, prognosis, prophylaxis and treatment for genital abnormality. Part 2. In Practice, $11,156-164$.

Ricketts, S.W. (1997): The treatment of equine endometritis with intrauterine irrigations of ceftiofur sodium: a comparison with mares treated in a similar manner with a mixture of benzylpenicillin, neomycin sulphate, polymixin B sulphate and furaltadone hydrochloride. Pferdeheilkunde, 13, 486-489.

Ricketts, S.W. (1999): The treatment of equine endometritis in studfarm practice. Pferdeheilkunde, 15, 588-593.

Ricketts, S.W. and Alonso, S. (1991a): Assessment of the breeding prognosis of mares using paired endometrial biopsy techniques. Equine Vet. J., 23, 185-188.

Ricketts, S.W. and Alonso, S. (1991 b): The effect of age and parity on the development of equine chronic endometrial disease. Equine Vet. J., 23, 189-192.

Ricketts, S.W. and Barrelet, A. (1997): A retrospective review of the histopathological features seen in a series of 4241 endometrial biopsy samples collected from UK Thoroughbred mares over a 25 year period. Pferdeheilkunde, 13, 526-530.

Ricketts, S.W. and Curnow, E.W.M. (1988): Caslick's vulvoplasty for the correction of pneumovagina in mares. In Practice, 10, 204208.

Ricketts, S.W. and Mackintosh, M.E. (1987): The role of anaerobic bacteria in equine endometritis. J. Reprod. Fert. Suppl. 35, 343351.

Troedsson, M.T., Crabo, B.G., Ibrahim, N.M., Scott, M. and Ing, M. (1995): Mating-induced endometritis: Mechanisms, clinical importance and consequences. Proc. $41 \mathrm{st}$ Ann. Conv. Am. Ass. Equine Practnrs, 11-12.

Watson, E.D. (1988): Uterine defence mechanisms in mares resistant and susceptible to endometritis: a review. Equine Vet. J., 20, 397410.

Professor Sidney W. Ricketts, LVO, BSC, BVSc, DESM, FRCVS. Mrs Annalisa Barrelet, BVetMed, MS, CertESM, MRCVS.

Beaufort Cottage Laboratories

High Street

Newmarket

Suffolk CB8 8JS, UK.

Tel.: $+44(0) 1638663017$

Fax: +44(0)1638560780 